\title{
FREEDOM IN CULTURE - SYMBOLS AND MYTHS IN BUILDING CULTURAL IDENTITY
}

\begin{abstract}
This article refers to a broadly understood issue of freedom usage in culture. It discusses the relationship between the Greeks and Macedonians, concerning the use of the name Macedonia and the image of Alexander the Great in the names, culture and symbols of both countries. The author reviews a problem of deriving benefits for one culture from another's heritage, exemplified by Romania as the heir of the Roman Empire. Some consideration is offered also with regard to legality of such procedures and the reaction of the international opinion. The Author provides specific and undeniable examples of relevant behaviours and approximates possible scenarios of relevant situations in the future with consequences to which such conflicts may lead.
\end{abstract}

Key words: culture, freedom, relations, Greeks, Romanians

This article raises issues of using symbols and myths in the process of shaping cultural identity based on the cases of Macedonia and Greece. The phenomenon is fairly prevalent, while the countries I have chosen are not the only ones that make such efforts. The usage of these two cultural mediums, namely symbols and myths, is a reference to a broader concern, which is freedom in culture itself. A fundamental question arising in this context may be formulated in the following way - are citizens really enjoying a vast array of rights, liberties in democratic European countries in the $21^{\text {st }}$ century or rather, are they witnessing progressive censorship, along with limitations on freedom of speech and action? A further question that develops from that above concerns whether culture is a realm where no

${ }^{1}$ PhD Student; Jagiellonian University in Kraków; e-mail: lukasz.krzak@student.uj.edu.pl. 
restrictions are conducive to creativity and one where there are no limitations imposed on using its products by individuals, groups, communities and societies. I propose to answer these questions within the context of the European Union as the entity which speaks out on international conflicts and disputes.

The European Union, as an institution with a rich history and multiple perspectives, unites the countries of Europe (Davies, 2010, p. 1125). The majority of the countries of the Old Continent are part of it, and in spite of their many vested interests, are able to work out compromises. The EU constitutes a system which is made up of representative bodies and departments, whose overriding goal is multilayered co-operation and the avoidance of situations from the $20^{\text {th }}$ century when nearly the entire world was engaged in two bloody global wars. In order to find a common interest and strengthen its status among the Member States, the EU must appeal to events and symbols which provide the guarantee of existence and secure its position in history. Symbols are an important element of the identification process and form an emotional attachment to institutions (Stradowski, 2013, pp. 157-158). The EU anthem, namely Ode to Joy by Ludwig van Beethoven, a shared European currency, the EU flag, European Day which occurs on the $9^{\text {th }}$ of May, or the motto "united in diversity" may be classified as such symbols (Skrzypczak, 2010, p. 212). This motto underscores that the EU safeguards cultural diversity while, at the same time, defining the axiological foundations of unity. In building its own identity, this refers to aspects of European history and culture which constitute fundamental values. These are Christianity, antiquity, democracy, respect for the rights of minorities, acceptance, communication and peaceful dialogue, all of which build close ties among all its members (Paleczny, 2008, p. 57).

Many times these premises are put to the test. Among instances of co-operation, numerous conflicts occur in Europe on many levels, from those which are economic down to those which are ethnic. One example is the Greek-Macedonian dispute. Although I use the term "Macedonia" regarding the eponymous country, this term is not acknowledged by everybody to be correct (Karadzoski \& Adamczyk, 2015, Wilczak, 2018). If I had used this name to describe the Greek region, already known from ancient times, then I would have won Greeks' support and recognition. Unfortunately, Macedonians cannot expect that. Greeks do not approve of the name in the context of the existence of the country neighbouring them. They do not allow its usage either in full or in part. Although the acronym, 
FYROM (the Former Yugoslav Republic of Macedonia) has been thus far acceptable, this was only given temporary approval (Pietruszewski, 2008, Wilczak, 2018).

I shall cite the history of the shaping of Macedonian statehood regarding its connections with the Greeks as it is a starting point for understanding both parties in the conflict, as well as further reflections.

Ancient Macedonians were the descendants of the Dorian tribe, thus the same as their Greek neighbours. They also spoke similar languages. They were one of many groups inhabiting the Balkan territories in ancient times. They played an important role, along with Thessalians and Epirots, since the $4^{\text {th }}$ century BC when they became the Hellenes. Living in the mountains at the meeting point of two cultures, they were the subject of an identity which was difficult to ascertain. Greeks regarded Macedonians as a people which could trace back their origins to a similar cultural circle (albeit one understood as having a barbarian language and beliefs), with certain differences, such as monarchy being the political system established in Macedonia. In view of the fact that they partook in the Olympic games, they were considered Hellenes. Macedonia emerged as a hegemonic force in the region over time and brought other city states under its control. Its glory days occurred during the reign of Philip II of Macedon and his son, Alexander the Great. They were annexed to the Roman Empire in the $2^{\text {nd }}$ century C.E. Subsequently, Slavic settlers began to flock in these lands from the $4^{\text {th }}$ century C.E. These territories were inhabited by many peoples in latter centuries and each one left their stamp on relations in the Balkans. Upon the decline of Byzantium, Serbs, Turks and Greeks wielded power in these lands. Each of the conquerors strove to pursue the policy of nationalisation towards their subjects, which led to divisions within society (Hroch, 2003, pp. 49-50).

Upon the collapse of the Ottoman Empire, the partition of Macedonia then followed. Territory inhabited by many nations of diverse provenance and denominations (Pietruszewski, 2008, Felczak \& Wasilewski, 1985, pp. 367-368) resulted in the awakening of modern-day Macedonians' national awareness. In the face of attempts made at annexations by their neighbours, who only promoted historical arguments in favour of legitimising the occupation of their lands, Macedonian peoples put up resistance engendered by the will to establish their own independent country. Up to the First and Second World Wars, ethnic Macedonian lands were part of adjacent countries. The process of denationalisation and a ban on speaking 
their own language got under way. Christians were displaced to Bulgaria, and Muslims to Turkey (Ślupkov, 2011) after the Balkan wars. During the Second World War, Macedonians served in ranks of the communists who, in return for help, promised to establish a federal Greek state in which Macedonia would obtain full rights. After the end of the war, a subsequent civil war broke out, as a result of which they were defeated by Greeks and which led to reprisals and the mass displacement of entire families. The names of towns, villages, as well as surnames were changed to Greek while the Macedonian language was forbidden to be used in public life. Corporal punishment, imprisonment, and even displacement to desert islands were inflicted for the violation of these rules in order to undermine the national and cultural identity of these emigrants. Efforts were also made to uproot the element of Hellenic heritage from Macedonian history and acknowledge them as a "Slavic language-speaking minority" (ibid.). Policies implemented against Macedonians led to the exodus of the nation, including emigration to Poland. Returning was made impossible due to obstacles put in the way of those who sought to join their families, as well as because of conditions in the country itself, which had split into three small homelands. These were: Aegean Macedonia, with its capital in Solun (Greek Thessaloniki); Vardar Macedonia, with its capital in Skopje; as well as Pirin Macedonia situated in Bulgaria, where a policy of Bulgarisation was pursued towards these inhabitants in order to break any ties with the Greek legacy (Pietruszewski, 2008, Śmieja, 2009). Raised beyond their boundaries as Greeks, Macedonians came across an ethnically and culturally divided land. "Aegeans" were not welcomed by privileged "Vardars" as they were able to cross the Greek border without restraint. Moreover, having deprived "Aegeans" of their wealth, they have left them without any sense of close links with the country.

The period of 1967-1974 was the time of rule of the Greek military junta, the so-called "Regime of the Colonels". It was the period of denationalisation, exile and denunciations by neighbours. Despite the fact that socialists subsequently rose to power, the situation was not subject to change in principle. Although Macedonians only could return to the country unobstructed, they were required to signing up an oath of loyalty and change their surname to sound Greek. With accession of Greece to the EEC (European Economic Community), Macedonians expected their neighbours to change their approach (Strzałkowski, 2018). In spite of many mediation efforts, the situation did not improve. 
Greeks feared that Macedonians were eager to usurp their achievements and culture, leading to review of their administrative frontiers. Since they were treated as a fifth column, they aspired to obtain the same rights as Greeks and be acknowledged as rightful citizens. They currently comprise $2 \%$ of the population in the Greek province of Macedonia. Even though they have been recognised as a national minority, they are still not entitled to form associations, which is considered a violation of the European Convention on Human Rights (Patek, Rydel, Węc, 2003b, pp. 123124). Although they are treated as a national group in Bulgaria, in the political sense, this does not concern ethnicity as they are perceived to be part of the Bulgarian nation. They are treated as fellow countrymen in Serbia since the existence of Macedonians as a separate nation is not recognised there (Pietruszewski, 2008).

How did this come to be a conflict over names and symbols? The Soviet-led Comintern acknowledged the existence of Macedonia in 1934, the inhabitants of which were Greeks, Bulgarians and citizens living within the limits of what was then Yugoslavia. Subsequently, Josip Broz Tito gave a new name to this region in 1944, namely the Socialist Republic of Macedonia and codified the language using dialects spoken in this land. An independent Republic of Macedonia emerged upon the collapse of Yugoslavia at the beginning of the 1990s. For Greeks, this was a temporary arrangement which had grown on transitory Balkan soil and expecting that when the post-communist order was to be brought into effect, the name would change too (Bodalska, 2018). However, it did not happen so. Macedonians, who did not have their own flag but instead used as their symbol the Star of Vergina, the burial site of Phillip II of Macedon, began to take steps on the international scene as an independent country while at the same time exposing themselves to the risk of being invaded by a powerful neighbour.

As the Greeks are anxious that Macedonians are willing to lay claim to their heritage and land, they remain unconvinced regarding conceding the name "Macedonia" to FYROM. Relations are tense to such an extent that the UN has intervened and negotiated the change of flag and constitution to reassure the Greek side since the Republic of Macedonia recognised the star/sun of Vergina as their emblem in 1992, an emblem officially reserved for Greeks (Biernacka-Rygiel, 2015). Both parties, however, identify with this symbol. It is an element of cultural identity for contemporary Macedonians, a link with the former Macedonia whose empire, history, culture goes far beyond the framework of the present country. Subsequently, 
in 1993, Greeks used it as the official emblem of the region of Macedonia within the borders of their country, which was to identify it as a reference to its antique and ancient traditions. Not being satisfied with the situation, Greece imposed an embargo. Upon UN intervention, the Greeks lifted sanctions imposed earlier on their neighbours, although they had an effect in that the Macedonian side renounced of all territorial pretensions and changed its flag to an eight-rayed sun. In addition, the Turks joined in, which owing to their own conflict with Greece, supported the Macedonians in their struggle for acquisition of the right to their own identity and national symbols. As their maritime borders are under dispute up to today, Turkey was able to exert pressure on the Greeks by supporting a weaker neighbouring state.

Let us, therefore take a closer look at the famed warrior who, as with the name of the Macedonian state, is an object of controversy. Alexander the Great is a symbol of both sides, an ancient figure who reinforces and supports the historical and cultural identity of either nation (Davies, 2010, pp. 135-136). To Greeks, he is regarded as a symbol of great glory and victories, while at the same time reminding Europe of who first laid the foundations of philosophy, science and democracy. According to Macedonians, however, Alexander is the figure who has given them the right to their own identity, their own state, and is considered the most famous and well-known of all Macedonians. Indeed, the ancient ruler is ubiquitous in Macedonia. Apart from monuments erected in his honour, his name is given to streets, airports or motorways, while the personal names of Alexander and Philip are among the most popular. It is incomprehensible to Greeks, however, that a nation which nowadays has more in common with the sphere of Slavic culture, identifies with Greece and considers itself the heir of Alexander the Great. It is worth noting that the Macedonians of today are more Slavic than Greek. The region of Macedonia, however, is an internal part of Greece and Greeks consider themselves solely entitled to refer to the legacy of the illustrious conqueror of Persia. In the present-day rhetoric, Alexander is being juggled around as a symbol. Thus, the airport in Skopje bears his name, whereas the Greeks have named the airport in Thessaloniki in honour of Macedonia, which is to aimed at signifying the strong devotion of their nation to the region. On the other hand, Macedonians have raised monuments, such as one worth a few million euro in Skopje, which represents "a warrior on horseback". It is not difficult to guess who the warrior is. This led to an inflammation of relations between 
Skopje and Athens and further obstruction of the accession of Macedonia to the European Union and NATO (Wilczak, 2018).

Moreover, in Athens it is easy to notice many motifs related to Alexander the Great, such as those on T-shirts, mugs, or little busts at souvenir shops. Associated with Greece and antiquity, he presents a unique attraction to tourists. If one pays a visit to the military museum, one will find their way to a separate room dedicated exclusively to the warrior. Mockups of parts of his military campaigns are exhibited there together with display of the 1956 movie Alexander the Great, starring Richard Burton. On display are replicas of armour and weaponry, maps presenting his journeys, and the entire legacy Alexander left upon his premature death. Interestingly, one may notice across inscriptions everywhere citing: "Alexander the Great" - not Alexander of Macedonia. Thus, Greeks' attitude towards the warrior itself is unambiguous and requires no additional commentary.

The Macedonians, however, are ready to meet half way. Although they are willing to change provocative names given to streets, motorways and the airport, as well as add qualifying adjectives such as North, Vardar, Upper to their country's name, this is still unacceptable to Greeks. It is necessary to mention steps undertaken by the government of Macedonia, and more precisely nationalist parties, who use populist slogans that meet with favourable reception and thus add fuel to the flames.

What kind of policy should the European Union adopt towards the Greek-Macedonian conflict? While there are a few solutions, it is certainly impossible to opt for one that will satisfy both parties as one party will always be forced to make concessions. Although Macedonia will probably be this party due to an increased inclination to compromise, the Greeks must limit their range of demands to those which are more feasible and which will not negate the existence of Macedonians, who having shaped their own cultural identity, constitute an independent nation with a turbulent history in a borderland country. ${ }^{2}$ The question may be posed as to what constitutes cultural identity. This is defined as a variety of collective identity and a certain persistent identification of a group of people with a cultural setting. These include the customs, outlooks and ideas which solidify the unity of a group. This identity distinguishes us from others

${ }^{2}$ Borderland country is characterised by blending influences of diverse countries and cultures, and also relatively few years of existence. 
which creates a certain newness out of a group, a sense of exceptionality (Waszczyńska, 2014).

The European Union is grappling with many domestic issues today. Established after the end of the Second World War as an economic community of unclear political-institutional frameworks, it was essential in the process of uniting Europe. At present, it enjoys a high level of confidence, albeit not on all grounds, especially as regards issues of migration and terrorism (47\% of mistrust among Europeans) (Komisja Europejska, 2018). Brussels is remote from many centres of Central and Southern Europe, who perceive it as a mediator dictating certain solutions not necessarily consistent with the tendencies and sentiments in a given country. This is related to a lack of specialised institutions of cultural integration thus far. A European Union oriented towards economic strategy and politics does not always take historical-cultural factors into consideration when taking decisions. In order to rationalise processes, schemes of building a common identity ought to be implemented as Europe is both multinational and multicultural (Skrzypczak, 2010, p. 204). To help with its construction, researchers have put forward two positions, namely essentialist and constructivist. The first of these is peculiar to traditional societies and pertains to a belief in a common ancestry, a quest for history and myths helpful in building cultural identity. The second of these is characterised by a constant process and a lack of stability (Skrzypczak, 2010, p. 206).

The already mentioned cultural identity is an ambiguously described concept (Skrzypczak, 2010, p. 205). The term "culture" alone has been awarded many definitions (Bogucka, 1991, p. 1, Świątkiewicz, 2002, p. 16). A common feature they hold are individuals and communities, namely "entities". These are the ones who create culture, which comes into existence and develops along with the human being, its moderator. It is of a personalised nature, while even in ruminations on material culture, we mean "the human factor" both as the author and recipient. These individuals own their identity, with the components which distinguish them including the following:

- National spirit

- Historical memory

- Anticipation

- Territory

- Awareness (ibid.). 
All these attributes create a link with one's culture and build the cultural identity of a given group, nation, etc. Identity makes references to the cultural world, elements of symbolic reality, which allow one to distinguish categories of own and foreign (Pietruszewski, 2008). Aside from the European awareness of many nations, which is buttressed by the EU itself and its governments, there is currently a great number of cultural identities in Europe. Each state, or ethnic group displays their own, which forms an interesting mosaic and conglomerate, although, on the other hand, this is conducive to conflict.

The European Union is not only a federation of states, but also a "Homeland of homelands" in a broader context (Skorowski, 2005, pp. 26-27). One of principal objectives of the EU should be cultivating the cultural heritage of each member state. This does not concern full unification but cooperation in various fields, without the need to force one into renouncing one's own identity. The EU ought to make every effort to support not only countries but also ethnic groups in the sense of their own value and uniqueness. It is unacceptable for members of the EU, namely the Greeks to discriminate against their Macedonian national minority by not granting them fundamental and guaranteed rights. The European Union reacted too late to events in this part of Europe, which took place not earlier than the 1990s. As far as the Greek-Macedonian conflict is concerned, it should be settled amicably. The case is difficult to such a degree that symbols used by two countries are similar. Macedonia, which bears its own identity, will not accept assimilation, incorporation and is hoping not to be pushed to the margins of Europe either (Suchocka \& Królikowska, 2014, p. 82).

We know from everyday life how important the cultivation of national symbols is. The example of Macedonia and Greece is not an unusual case in global terms. Within the concept of the self-determination of nations, each state is entitled to take advantage of the legacy of the cultural sphere from which it originates. In the past, Poles were referred to Sarmatians, while Hungarians sought their ancestors among the Sumerians. As regards Macedonia, there is no question of discussing the stealing of symbols since it is a fairly extraordinary case. The state in question, which has gained its independence recently, is striving to write its own history and the figure of Alexander the Great is a good example of legitimising and raising the profile of Macedonia as a country of centuries-old traditions. As their rights should be respected, whilst not forgetting about Greeks, the target of European Union is to reach a proper consensus in compliance with effective 
rights and international standards. As the EU itself was, as an institution, also involved in creating and seeking out symbols for its unification with the European continent, it should be a good peacemaker in settling this dispute in which the aggrieved party is undoubtedly Macedonia, a country unable to unite with the rest of Europe.

To my mind, the idea of compromise is possible in the current European situation as no one can either take over or restrict anyone's cultural identity. Such an example may be found in the case of Romanians and Italians, who share the tradition of the Roman Empire, as well as Russia and Bulgaria which relate to the concept of the Third Rome.

The above-mentioned Romania shall be the subject of further deliberations on freedom in culture, regarding the use of symbols (the symbol in this case being the Roman Empire). Additionally, the issue of myth is worth taking note of since the theories of many Romanian researchers classify it exactly as the pursuance of historical policy.

Romania is a country which stakes out a claim to the inheritance of the Roman Empire, entirely due to the fact that the province of Dacia was part of this once-great empire. This land was conquered by the emperor Trajan and was included in the empire, while its historical borders partially overlap with today's Romanian frontiers (Jaczynowska, 2002, p. 522). The shortlived period of Roman rule in these territories surely left mark on their subjugated peoples. Although the influx of cultural exemplars, religion and administration caused the lands to be strictly governed by the empire, the question remains whether a period of just over a century and a half could have brought about a complete Romanisation of the population.

The regions along the Danube were very attractive as transport on the river and its control yielded high profits. Thus, Rome directed its attention to the Dacian tribes inhabiting these lands. Although two campaigns conducted by the empire cost a great deal of effort, the brave Dacians under the command of Decebalus were conquered successfully. While Roman rule did not last long, it left an indelible stamp. As Roman settlers and legionaries were representatives of highbrow culture, they exerted a strong influence on their subjected peoples (Rumuńskie mity, 2009).

After the short-lived rule of Rome, these lands first came under the influence of the Goths before being seized by Slavic tribes. In later centuries, the Pechenegs and Byzantines arrived. Slavic incursions resulted in supplanting Byzantine influences in these territories (Wendt, 2014, p. 76). In a subsequent period, these regions came under rule of Kievan Rus', 
Hungary (Hroch, 2003, pp. 11-14), Turkey, and even the Polish Republic (Szczur, 2003, pp. 493, 509, 511, 541), that is countries originating from completely different cultural spheres (Wendt, 2014, p. 77). Under rule of the Ottoman Porte, the Phanariotes, namely Greeks dispatched from Constantinople as lieutenants, wielded power. In the $17^{\text {th }}$ century, Russian and Austrian influences were also noticeable. Therefore, the question may be posed as to why Romanians have connected a kind of myth of common roots with the empire. The answer to this lies in events that occurred in the $19^{\text {th }}$ century.

Thus, attempts were made on the combined Principalities of Moldavia and Wallachia (1859-1861) (Davies, 2010, p. 886) ${ }^{3}$ to romanise the country, which was the conglomerate of a great many of cultural influences due to constant changes regarding the nationality of Romanians (Moldavians and Wallachians had begun to be called Romanians in these regions from the $19^{\text {th }}$ century on) (Willaume, 2011, p. 242). The authorities contributed to revision of alphabet, which was enriched with a great number of Latin words, and to the changing of the names of towns. The example is Cluj, to which the name of Napoca was added, which was to commemorate a bygone Roman factory in these territories. Monuments of a she-wolf feeding the twin brothers, Romulus and Remus, were put up in many other towns, with legend having it that one of brothers had been the founder of Rome. All these measures were aimed to show that Romania is the lineal heir to the legacy of the Roman Empire.

When subjecting the Romanian language to observation, a close similarity to Italian and French may be observed, while it also belongs to group of the Eastern Romance languages. Cyrillic script was removed as the alphabet since 1860 and was replaced with the Latin alphabet. Slavic influences were meticulously cleansed away and connotations with the Occident were restored. Nowadays, as only a small percentage of the language is of Slavic origin, Romanian is, therefore, easily comprehensible to an Italian. Ethnic Romanian lands in 1859 that preached adherence to the cultural sphere of Slavs, chose the pro-Western course due to the influence of politicians (Malessa-Drohomirecka, 2016). From today's perspective this is a curious phenomenon, since 250 years ago the language was regarded as Slavic, called Wallachian, and written in Cyrillic script. Indeed, Romanians

\footnotetext{
${ }^{3}$ Duchies had already begun to develop in the $14^{\text {th }}$ century.
} 
were called Wallachians until the $19^{\text {th }}$ century. Moreover, the etymology of the word "Wallachian" traces back its origin to Roman times. Populations of romanised shepherds bore such names, although it literally means a coarse human or a vagrant (Willaume, 2011, p. 242).

The aspirations of Romanians, therefore, should be considered with a certain reserve. The attribution of the descent of present-day Romanians to Roman settlers needs to be regarded as a myth since history has not found an irrefutable source of evidence to acknowledge this as a fact (Rumuńskie mity, 2009). Nevertheless, alluding to this legend has allowed Romanians to build their own national identity. Thus, a country under the influence of the Middle East and the Slavic cultural sphere felt the need to create its own unique identity than espouse that of one of these sides. The attribution of Roman descent was distinguished by Romanian historians since they are more recognisable than barbarian Goths who were present in these territories too. In their view, Romania was and still is "a Roman island in a sea of Slavs" (ibid.). Moreover, the attribution of their origins to the Romans serves the purpose of ennobling the pedigree, consolidating the nation and broadening the Romanian spectrum of historical events. In spite of efforts to debunk the myth of Roman descent during the communist period and underscore the country's Dacian roots by nationalists, Romania is consistently striving to allude to a tradition of being the progeny and heirs of Rome. Pro-Western parties aim at linking the country with the Western cultural sphere (Malessa-Drohomirecka, 2016). This is difficult due to the ethnic mix of inhabitants of Romania, which is conducive to volatile sentiments in society and decentralisation. Integration with the EU is, therefore, not at the highest level. In addition, there are many stereotypes prevalent in Romania, while a significant proportion of country's population is rural, and eurosceptic in general.

Although the origin of Romanians from Roman settlers is considered to be a legend, it is commonly said that in every legend there lies a grain of truth. There is no denying the fact that these lands were influenced by the Romans. Historical monuments from the time of the empire times bear testimony to it. Romanians - that is citizens of Rome who have low selfesteem, have used their connections with the empire to provide the basis for their nationality. It is important to remember that their lands have remained a peculiar cultural mosaic until today. It was also influenced by the policy of superpowers who treated Romania as their dominion and sphere of influence. As a rule, apart from a few exceptions in history, Romanian 
statehood was not uniform, and lands consolidated today were under influence of countries from various cultural spheres (Bulgarians, Turks, Russians, Hungarians). With such diversity to be taken into account, finding a common denominator was the one and only possibility to unite and show that despite the differences that divided them, there were common roots - namely Roman roots (Całus, 2015, pp. 9-15). During the short-lived reign of the empire in these regions, the full Romanisation of the Wallachian population was impossible. Moreover, the influences of civilisation would not have stood a chance of survival up to now if it had not been for the effort put by Romania into "dusting them off" and imposing them upon its citizens. Despite the efforts of nationalists to focus attention on the Dacians, ${ }^{4}$ Romanian society gladly adapted to its Roman roots, surely through their historical merits and an established empire. It is no accident that among the most popular personal names in Romania today one may find: Ovid, Adrian (originated from Hadrian), Romulus, Diana, Sabina, Claudia, Livia or Constantine. By deriving from a widely understood freedom in culture, and backed up by certain historical facts, which are exaggerated, Romanians may claim to be the heirs of the Caesars today, a claim which native-born Italians take with a pinch of salt. Nevertheless, an anecdote is to be heard among linguists, namely: "If you wish to find out whether a particular word was used in ancient Rome, go to Romania and make sure of it."

Freedom in culture is a privilege that offers many possibilities. Some people recall it due to a myth of common descent and their place in history, which builds historical memory, while others perceive it as quite the opposite, namely that it provides reasons for contention and animosity. Although the examples set forth here are similar, the Greek-Macedonian dispute seems to have more serious consequences as it is based on EU interference. ${ }^{5}$ Nevertheless, freedom constitutes a relevant element of present-day public discourse, namely the question of how much freedom

${ }^{4}$ The cultivation of commemorating Romania's Dacian roots is visible apart from its identification with Rome. Thus, Dacia is a popular make of car in Romania.

${ }^{5}$ Despite Macedonia having had the status of candidate for joining EU since 2005, its accession to membership has been effectively blocked by Greece. Even though the EU Commission concedes that the Greeks are infringing the law, no significant steps were taken. Macedonians feel as if they have been left stranded with no support from the EU, which they accuse of taking a protective approach towards Greece. 
may there be in a culture and when it may be limited, or whether it should be limited at all. In my opinion, on the condition that it does not belie the facts or leads to abuses and misrepresentations, this should be respected.

\section{BIBLIOGRAPHY}

Biernacka-Rygiel, A. (2015, December 20). Stosunki grecko-macedońskie, czyli konflikt sq̨siedzki o nazwę. Retrieved May 25, 2018, from http://blog.centruminicjatyw.org/stosunki-greckomacedonskie-czyli-konflikt-sasiedzki-Stosunkio-nazwe/

Bodalska, B. (2018, May 23). Koniec tymczasowej nazwy FYROM? Retrieved May 23, 2018, from https://www.euractiv.pl/section/polityka-zagraniczna/news/koniec-tymczasowejnazwy-fyrom/

Bogucka, M. (1991). Dzieje kultury polskiej do 1918 roku. Wrocław: Zakład Narodowy Imienia Ossolińskich.

Całus, K. (2015). W cieniu historii. Stosunki rumuńsko-mołdawskie. Warszawa: Ośrodek Studiów Wschodnich im. Marka Karpia.

Davies, N. (2010). Europa. Rozprawa historyka z historiq. Kraków: Wydawnictwo Znak.

Felczak, W., \& Wasilewski, T. (1985). Historia Jugosławii. Wrocław: Zakład Narodowy Imienia Ossolińskich.

Hroch, M. (2003). Małe narody Europy - perspektywa historyczna. Wrocław: Zakład Narodowy Imienia Ossolińskich.

Jaczynowska, M. (2002). Historia starożytna. Warszawa: Wydawnictwo TRIO.

Karadzoski, M., \& Adamczyk, A. (2015). Najważniejsze problemy Macedonii w procesie integracji z Unią Europejską. Studia Europejskie. 2, 27-44.

Kołakowski, L. (1995). O tożsamości zbiorowej. In K. Michalski, E.-W. Bockenforde (Eds.), Tożsamość w czasach zmiany. Rozmowy w Castel Gandolfo (pp. 47-49). Kraków: Wydawnictwo Znak.

Komisja Europejska. (2018, June 14). Komunikat prasowy. Standardowe badanie Eurobarometr z wiosny 2018 r.: na rok przed wyborami europejskimi zaufanie do Unii i optymizm co do jej przyszłości rosnq. Retrieved July 2, 2018, from http://www.google.pl/url?sa=t\&rct=j\&q=\& esrc=s\&source=web\&cd=1\&ved=0ahUKEwjX2Y2iklvcAhUCJ1AKHfyoBSkQFggvMAA\&url= http\%3A\%2F\%2Feuropa.eu\%2Frapid\%2Fpress-release_IP-18-4148_pl.pdf\&usg=AOvVaw320mFEKoen5XMplMd_Z4I

Malessa-Drohomirecka, M. (2016, December 21). Rumunia-między Wschodem a Zachodem. Retrieved May 23, 2018, from http://magazyn.o.pl/2016/monika-malessa-drohomireckarumunia-miedzy-wschodem-a-zachodem/

Paleczny, T. (2008). Socjologia tożsamości. Kraków: Krakowskie Towarzystwo Edukacyjne - Oficyna Wydawnicza AFM.

Patek, A., Rydel, J., \& Węc, J. J. (2003a). Najnowsza historia świata. (Vol. I). 1945-1963 ( $5^{\text {th }}$ ed.). Kraków: Wydawnictwo Literackie.

Patek, A., Rydel, J., \& Węc, J. J. (2003b). Najnowsza historia świata. (Vol. III). 1979-1995 $\left(5^{\text {th }}\right.$ ed.). Kraków: Wydawnictwo Literackie.

Pietruszewski, M. (2008, June 15). Kontrowersje na temat tożsamości macedońskiej. Retrieved May 23, 2018, from http://www.psz.pl/117-polityka/maciej-pietruszewski-kontrowersjena-temat-tozsamosci-macedonskiej 
Rumuńskie mity narodowe. (2009, September 9). Message posted to Na wschód 24. Blog o Europie Środkowo-Wschodniej: https://www.salon24.pl/u/nawschod/124389, rumunskie-mity-narodowe

Skorowski, H. (2005). Integracja europejska a tożsamość narodowa. In J. Kupny, M. Stępniak (Eds.), Kościół w Europie wobec wyzwań integracji (pp. 26-27). Katowice: Wydawnictwo Księgarnia św. Jacka.

Skrzypczak, K. (2010). Jaka tożsamość kulturowa dla dzisiejszej Europy? Refleksje. Pismo naukowe studentów i doktorantów WNPiD UAM. 1, 203-218.

Stradowski, M. A. (2013). Znaczenie symboli w wychowaniu obywatelskim. Seminare. Poszukiwania naukowe. 33, 153-164.

Strzałkowski, M. (2018, February 1). Macedonia: Mediator ONZ przybył do Skopje ws. sporu z Grecjq o nazwę kraju. Retrieved May 23, 2018, from https://www.euractiv.pl/section/ polityka-zagraniczna/news/macedonia-mediator-onz-przybyl-skopje-ws-sporu-grecja-onazwe-kraju/

Suchocka, A., \& Królikowska, I. (2014). Kreowanie tożsamości kulturowej jako wyzwanie XXI wieku. Colloquium Wydziału Nauk Humanistycznych i Społecznych. 4, 73-88.

Szczur, S. (2003). Historia Polski. Średniowiecze. Kraków: Wydawnictwo Literackie.

Ślupkov, I. A. (2010, August 1). Macedoński dylemat. Message posted to Macedonia: https:// www.salon24.pl/u/macedonia/213745, macedonski-dylemat

Ślupkov, I. A. (2011). Macedoński problem narodowy w Grecji w dokumentach KPG 1918-1940. Szczecin: Wydawnictwo Hogben.

Śmieja, W. (2009, July 26). Korespondencja ze Skopje - Macedończyk made in Poland. Retrieved May 28, 2018, from https://www.tygodnikprzeglad.pl/macedonczyk-made-poland/

Świątkiewicz, W. (2002). Symbole europejskiej tożsamości. Katowice: Muzeum Historii Polski.

Waszczyńska, K. (2014). Wokół problematyki tożsamości. Rocznik Towarzystwa Naukowego Płockiego. 6, 48-73.

Wendt, J. A. (2014). Regiony historyczne i podziały administracyjne na ziemiach rumuńskich. Studia z Geografii Politycznej i Historycznej. 3, 71-96.

Wilczak, J. (2018, February 5). Grecy nie zgadzajq się na "Macedonię". Chodzi o historie $i$ politykę. Retrieved May 24, 2018, from https://www.polityka.pl/tygodnikpolityka/ swiat/1736990,1,grecy-nie-zgadzaja-sie-na-macedonie-chodzi-o-historie-i-polityke.read

Willaume, M. (2011). Rumunia rozpoznana: historia Rumunii. Rocznik Lubelski. 37, 241-243. 